\title{
A tax compliance risk profile of guesthouse owners in Soweto, South Africa
}

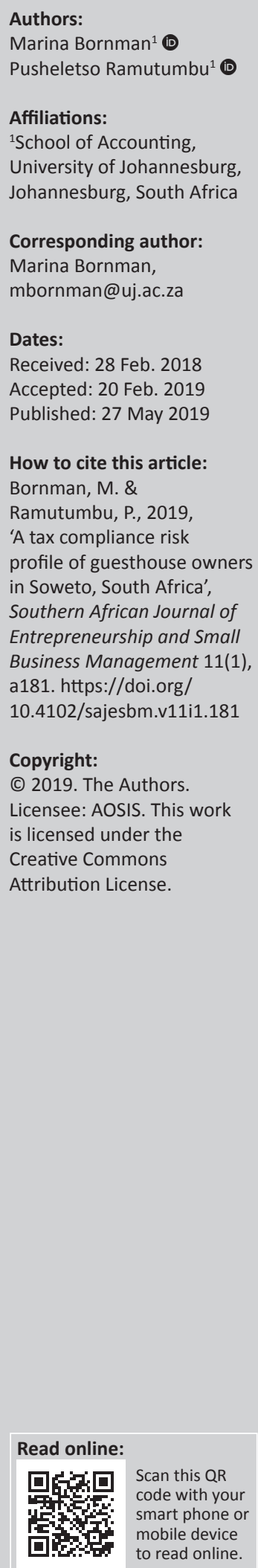

Background: A conceptual framework to assess the particular tax situation of small business owners identifies three key aspects that distinguish small business owners' perceptions of their tax obligation. These aspects are: they are likely to perceive more opportunities not to comply than employed taxpayers; they are likely to lack meaningful taxation knowledge and they are likely to frame the paying of taxes as a loss.

Aim: The aim of this article was to sketch a tax compliance risk profile of guest house owners in Soweto to suggest strategies to negate those factors that may negatively influence their compliance behaviour.

Setting: Tax compliance is a priority for tax administrations, especially in developing countries such as South Africa where small businesses are a high compliance risk group. Small guest houses' income is usually variable and/or cash-based and not easily verifiable against thirdparty data, which creates a high risk of non-compliance.

Methods: A mixed methods research approach was followed. Empirical evidence in the form of semi-structured questionnaires administered face-to-face with 23 guest house owners in Soweto was statistically and thematically analysed to compile a profile of the tax compliance risk according to the framework for tax compliance behaviour of small business owners.

Results: Factors such as age, gender and tax morale show favourable results for tax compliant behaviour. However, perceptions of fairness, perceived opportunity for non-compliance, knowledge deficits, decision frames, industry, business size and social norms embrace a high risk of non-compliance for this population.

Conclusion: Information pointing out the factors that could negatively influence tax compliance behaviour in this population was obtained. Strategies for empowering small business owners to comply voluntarily with their tax obligations are suggested and include, for example, taxpayer education and improved communication efforts from the revenue authority.

Keywords: Tax compliance; guesthouse owners; tax knowledge; fairness perception; social norms; tax morale.

\section{Introduction}

Dealing with tax compliance is a priority for tax administrations, especially in developing countries armed with limited resources but faced with massive development targets (The Commonwealth Association of Tax Administrators 2006:5). To curb non-compliance, many countries' tax administrations adopted the use of compliance models which usually 'differentiates between the economic, psychological, and social circumstances of taxpayers' (D'Ascenzo 2015:88). D'Ascenzo further points out that 'service and enforcement' and strategies of 'prevention is better than cure' are the more holistic approaches for improving levels of compliance by modern tax administrations.

Evans and Joseph (2015:50) argue that South Africa (SA) could do more to improve tax compliance and address corruption in order to safeguard its existing tax base. In this regard, tax compliance means taxpayers should calculate their tax liabilities correctly, file their returns on time, declare to South African Revenue Service (SARS) what their income is and duly pay what is due (SARS 2014:18). McKerchar and Evans (2009:25) propose some appropriate and effective strategies to improve taxpayer compliance in developing economies. The strategies are grouped into four broad categories: (1) creating a more effective tax administration, (2) fostering voluntary compliance and enhancing taxpayer morale, (3) strengthening and enforcing compliance and (4) tackling the shadow economy. 
In 2012, the SARS launched its compliance programme that points out priority areas where compliance is not at the levels that it should be (SARS 2012:9). Amongst other priority areas, SARS identified small businesses as an area on which to focus its attention over the period of 2012/132016/17 (SARS 2012:18). D'Ascenzo (2015:96) states that small business is a key sector for many economies, and because of the risk of them operating in the cash economy and the important role they play as value-added tax (VAT) collectors, many tax agencies devote a high percentage of their resources to this sector. Research performed by SARS indicates that in most instances, small, medium and microenterprises (SMMEs) are considered to be a high compliance risk group in most countries because of their large numbers and income which are variable and not easily verifiable against third-party data. The research findings also reflect that the commercial setups of SMMEs often lack welldeveloped structures for record keeping, independent audits of accounts and cash handling that helps to minimise the risk of under reporting (SARS 2012:18).

Although SARS has not issued a new compliance programme document in the years after the initial 2012/13 to 2016/2017 document, it can be argued that small businesses' tax compliance is still a priority for SARS.

In SARS' strategic plan for 2015/16-2019/20, the small business sector is not identified as a strategic risk area facing SARS; however, small businesses are still identified as a key priority area to which SARS commits to making it easy for them to comply with their tax obligation (SARS 2016a:42). In addition, in 2013, the Davis Tax Committee (DTC) was mandated by the Minister of Finance to examine the tax system and its impact upon the promotion of small- and medium-size businesses (DTC 2013).

South African Revenue Service declares in its strategic plan that it seeks to increase voluntary compliance across a broader taxpayer base and has indicated that it will realise these compliance objectives through better understanding of taxpayer circumstances, needs, attitudes, abilities and behaviours. South African Revenue Service has declared that:

\footnotetext{
... we will use our understanding of the different taxpayers to inform and focus our efforts where we can have the biggest effect on compliance. This means that we will create a good balance between our education, service and enforcement interventions. (SARS 2014:18)
}

Olsen (2015:31) believes that understanding taxpayer behaviour is 'at the core of being a wise and effective administrator' and Carroll (1987:320) has also called for a better understanding of taxpayer behaviour by tax authorities. It is submitted that 'understanding taxpayer behaviour' is an example of a 'prevention' strategy which may guide a tax administration's interventions aimed at improving tax compliance. The present article intends to contribute to an understanding of taxpayer behaviour, more specifically - that of guest house owners in the small business sector.

\section{Small businesses in South Africa, the tourism industry and guest houses in Soweto}

A 2016 report on the SMME sector commissioned by the Small Enterprise Development Agency (SEDA) reveals that there are more than 2.2 million SMMEs in SA of which $43 \%$ operate in the trade and accommodation sector (Bureau for Economic Research 2016:2). However, it must be noted that SMMEs in SA consist of firms ranging from medium-sized enterprises, such as established traditional family businesses employing more than 100 people, to informal micro-enterprises (Bureau for Economic Research 2016). The 2017 Tax Statistics indicate that 4967 small business corporations (SBCs) were registered as taxpayers in the catering and accommodation sector and only 2369 of these reported positive taxable income for the 2017 year of assessment (National Treasury and South African Revenue Service 2017:62).

Not all small businesses are registered as SBCs for tax purposes, as specific criteria apply to be registered as an SBC (see Section 12E(4) of the Income Tax Act No 59 of 1962). It is therefore not possible to provide an accurate picture of the number of small businesses in the accommodation sector in SA, but indications are that they do play an important role in contributing to the fiscus and the economy.

Outwardly, the tourism industry and specifically guest houses appear to fit this profile of a high-compliance risk-type business because it is an industry where cash transactions may be dominant and many guest houses could, in fact, be part of the shadow economy. Evans and Joseph (2015:37) reason that, based on the estimates that are available (revealing that SA possibly had a shadow economy of $25.2 \%$ in 2015), the shadow economy in SA represents a real challenge for policy makers. The shadow economy (or underground economy) is typically known to 'escape taxation' (The Commonwealth Association of Tax Administrators 2006:14). In a guest house setup, record keeping may easily be blurred between personal and business expenditure which could lead to over-deduction of expenditure for income tax purposes and result in tax noncompliance. A study by Ramutumbu (2016), surveying 23 guesthouse owners in Soweto, reveals that these entrepreneurs have high levels of tax morale (or willingness to be tax compliant) but also reports that lack of knowledge is an obstacle to compliance.

This article sets off by providing an overview of the supporting literature. The main focus is a discussion of the conceptual framework whereafter the aim of the study is presented. The research methodology is then described, followed by the findings of the research. Lastly, a discussion follows on the practical and theoretical implications of the research.

\section{Conceptual framework}

A guidance note on Managing and Improving Tax Compliance published by the Organisation for Economic Co-operation 
and Development (OECD) Centre for Tax Policy and Administration (OECD 2004:7) defines tax compliance in terms of the extent to which tax payers comply with tax obligations in the four interconnected areas of registration, filing, reporting and payment.

It is not known whether the guest house industry in particular has low compliance levels. Kirchler (2007:21) reports on two studies, indicating that the shadow economy (thus businesses operating outside the formal sector and probably not registered for tax) in the services and entertainment sector (including restaurants and hotels) in Germany is estimated at $17 \%$ of gross national product. Research by the Commonwealth Association of Tax Administrators (CATA) also places the services industry in the top three industries likely to engage in tax evasion and avoidance behaviour (The Commonwealth Association of Tax Administrators 2006:24).

\section{Studies on tax compliance of small business owners in South Africa}

Ramutumbu's (2016) study attempts to understand the perceptions of SMME owners in Soweto towards tax compliance and was the first in SA in respect of black guest house owners. Other empirical studies pertaining to tax compliance in a South African context were performed in recent years but mostly across different sectors or with individuals and not small business owners. Some studies are mentioned below:

- Smulders (2006) - On the tax compliance burden of small businesses in SA. A survey conducted with tax practitioners representing clients from various sectors.

- Oberholzer (2007) and Oberholzer and Stack (2009) - A comparative study on perceptions of taxation of different population groups in SA. This study was aimed at individuals and not small business owners.

- Coolidge and Ilic (2009) - On tax compliance perceptions and formalisation of small businesses in SA. Based on large-scale surveys of formal and informal small businesses from various sectors.

- Naidoo (2012) - Aimed at investigating the views of micro-business owners (as expressed by tax practitioners) on the role that tax morale plays in low compliance levels with regard to turnover tax. Various business sectors were included in the sample.

- Bornman (2014) - Aimed at eliciting small business owners' opinions on being rewarded for tax compliance. Businesses surveyed were from the real estate and construction industry.

- Junpath, Kharwa and Stainbank (2016) - A survey on the attitudes of taxpayers towards tax compliance and tax amnesties in SA. The population surveyed included both individual taxpayers and owners and representatives of small businesses.

From the findings of the studies mentioned above, the general consensus is that the majority of taxpayers believe that it is every South African's civil duty to pay their fair share of taxes and it appears that tax morale is generally high amongst
South African taxpayers. South African Revenue Service's acknowledgement that there is an ever-growing culture of tax compliance in the country (SARS 2012:1) and their assertion that taxpayers' 'positive attitude to compliance' is one of their strengths (SARS 2016a:14) support this view. In recent years, however, SARS identifies increasing noncompliance by taxpayers and traders as a risk and also reports that they will continue their efforts on increasing compliance in the cash economy through education and further support (SARS 2018). In relation to small business' tax compliance, Kamleitner, Korunka and Kirchler et al. (2012:330) point out that most research suggests that small business owners or managers are more likely to evade paying taxes than other groups of taxpayers. Likewise, Coolidge and Ilic's $(2009: 18,19)$ research reports a 'habit' of non-compliance by small business owners, not only with taxes but also with local fees for electricity, water and sewerage. In a report on taxation considerations for small and medium enterprises by the DTC appointed in 2013 by the Ministry of Finance in SA to review various tax matters, it is suggested that small firms may regard the benefits of compliance as insignificant, given the high cost of regulatory compliance (DTC 2014:10). It therefore appears that small businesses in SA, and especially small businesses that may operate in the cash economy, can be regarded as high-risk entities for being non-compliant in tax matters.

Kamleitner et al. (2012:331) propose that in many cases, it is impossible to prove non-compliance and cite Webley's (2004 cited in Kamleitner et al. 2012) example of the US Internal Revenue Service estimates that only half of corporate non-compliance is detected. They suggest that increasing voluntary compliance amongst business owners is a worthwhile endeavour. In order to do so, an in-depth understanding of the factors fostering non-compliance and the factors contributing to compliance is essential.

Although it needs to be acknowledged that the tax compliance burden (cost, time and effort) plays a major role in the tax compliance outcome of small business owners, the present article focuses only on highlighting the particular tax situation of small business owners from a psychological perspective as represented by Kamleitner et al.'s (2012) framework.

\section{Factors influencing tax compliance behaviour}

The literature on tax compliance behaviour from a behavioural or psychological viewpoint has seen major growth since the 1960s. Kirchler (2007) provides a comprehensive overview of tax behaviour research and an OECD information note on understanding and influencing taxpayers' compliance behaviour describes the findings from a survey to member countries and studies of scientific literature on taxpayer compliance behaviour (OECD 2010:4). More recently, Pickhardt and Prinz (2014) and Hofmann et al. (2017) surveyed the main developments in this research area. Alm et al. (2012:33-39) discuss the different research paradigms for the 
analysis of tax compliance behaviour and emphasise the importance of considering all the actors (taxpayers, tax accountants, the tax authorities and the government), their behaviours and their interactions when exploring tax compliance behaviour.

The present article does not aim to describe the different approaches to tax compliance research nor to discuss the factors influencing tax compliance behaviour. Rather, compliance factors for a specific population are analysed using a specific framework. It will therefore suffice with a brief annotation on the factors influencing tax compliance as identified by the South African revenue authority in their 2012 compliance programme (SARS 2012:5). These factors are: a combination of individual values and norms, societal values and norms, belief in the justice and fairness of the system, the ease of compliance, the speed and accuracy of detection of non-compliance, the speed and accuracy of corrective measures and the severity or impact of the deterrent measures. Taxpayers' compliance behaviour is also influenced by attitude and willingness to pay their fair share, knowing what their obligations are, knowing how to comply, ease of compliance, legal treatment of some tax positions, an understanding of the possible consequences of non-compliance and the perception of a credible threat of detection of non-compliance.

\section{The tax compliance decision of small business owners versus individuals}

As a group, small business owners are much the same as other taxpayers. They have a great deal in common with individuals who earn a salary and even share views on, for example, law-abidingness and respect for authority (Ahmed \& Braithwaite 2005:23). The major differences appear to lie in feelings of competence to deal with tax matters, tax morale and perceived opportunities not to comply. Kamleitner et al. (2012:334-340) have identified the key aspects that distinguish small business owners' perceptions of their tax obligation. This is presented in a framework (Figure 1) and each factor is briefly described below.

\section{A framework for assessing tax compliance risk}

Figure 1 presents a framework depicting the factors influencing small business owners' tax compliance as suggested by Kamleitner et al. (2012:334).

According to Kamleitner et al. (2012:334), it appears that three key aspects seem to distinguish small business owners' perceptions of their tax situation from that of employed taxpayers: they are likely to perceive more opportunities not to comply than employed taxpayers; they are more likely to lack meaningful taxation knowledge and they are more likely to frame the paying of taxes as a loss.

The framework assumes that the three main factors play a universal role for small business owners, but also acknowledges that these factors are co-determined by interindividual factors such as age, culture, gender, and so on,

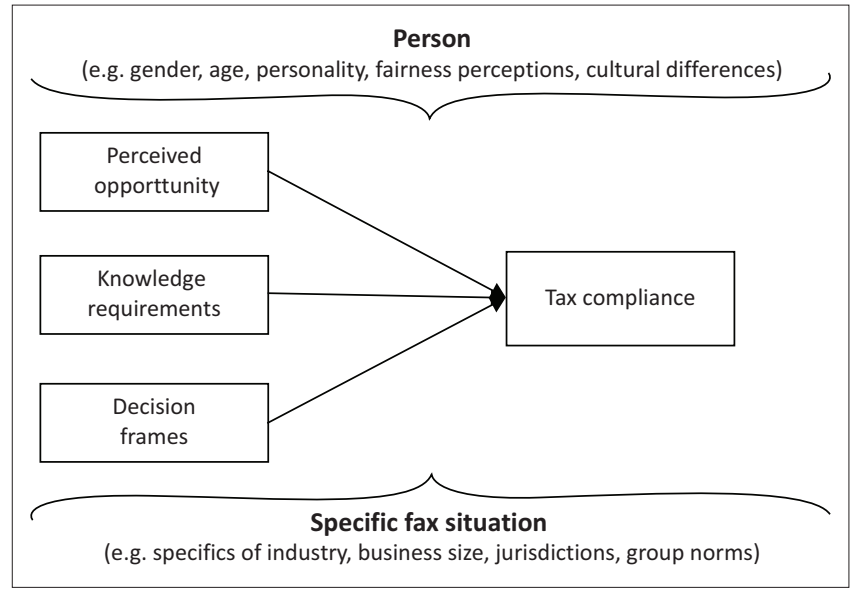

Source: Kamleitner, B., Korunka, C. \& Kirchler, E., 2012, 'Tax compliance of small business owners: A review', International Journal of Entrepreneurial Behaviour and Research 18(3) 334. https://doi.org/10.1108/13552551211227710

FIGURE 1: Framework of factors influencing small business owners' tax compliance.

and furthermore by situational factors specific to the small business such as industry, size, group norms, and so on (Kamleitner et al. 2012:334). A brief description of a selection of these factors (as they were used in the present study) follows.

\section{Person characteristics}

Age: Kastlunger et al. (2010:543) report that empirical studies consistently found a positive relationship between age and tax compliance. Older people tend to have a more positive attitude towards tax compliance (Braithwaite, Reinhart \& Smart 2010:257; Kirchler 2007:157).

Gender: A study using decision-making experiments Kastlunger et al. (2010:549) found that women and men differ regarding their taxpaying strategies and that women are more compliant than men. Their review of previous studies also reveals that women are more compliant than men, but they do point out that there are inconsistencies in empirical studies in this regard.

Fairness perceptions: Torgler (2003:22) suggests that the tax compliance literature has effectively exhibited that taxpayers' perceptions of fairness affect their willingness to pay taxes. Taxpayers' perceptions of fairness may be discernible as three components, namely:

- perceptions that taxpayers have regarding the fairness of tax laws (Kirchler 2007:74). Bazart and Bonein (2014:86) mention that perceptions of unfairness may result from 'differences in tax rules and fiscal parameters for identical taxpayers'

- perceptions on the manner in which the tax authorities use their powers to enact the laws. This corresponds with taxpayers' perceptions on how they are treated by the tax authority (Murphy 2005:566; Van Dijk \& Verboon 2010:87)

- Perceptions on just income distribution. Also named 'distributive justice', it refers to how a given pool of resources is distributed so that all social units receive what 
they are entitled to (Wenzel 2002:45). On an individual level, this relates mainly to a comparison of tax burden and tax-funded benefits with that of other taxpayers (Svetalekth 2016:194).

Tax morale: Torgler (2003:81) defines tax morale as the individual's willingness to comply, or stated differently, the intrinsic motivation to comply. Cummings et al. (2008) add that this intrinsic motivation arises from the moral obligation to pay taxes or the belief in contributing to society by paying taxes. Tyler (2006:313) submits that an internalised obligation is a characteristic of voluntary compliance and is derived from a person's desire to behave according to his or her own sense of personal morality.

\section{Perceived opportunity}

Kamleitner et al. (2012:335) suggest that there are two facets of 'perceived opportunity'. Firstly, there could be specific circumstances leading to opportunities to evade. They suggest that opportunities usually come about when tax filings are not entirely automated, resulting not only in more room for errors (unintended non-compliance) but also more opportunities for intended non-compliance.

Secondly, people can only capitalise on opportunities if they actually recognise them. It is submitted that unless a taxpayer knows the tax legislation and procedures well, many opportunities may remain unnoticed.

\section{Knowledge requirements}

It is proposed that small business owners' level of tax knowledge will, in part, determine their ability to understand and cope with the administrative and legal requirements of revenue bodies. Thus, higher levels of tax knowledge should make it easier to comply. Kamleitner et al. (2012:336-337) provide evidence on non-compliance as a result of the complexity of reporting and returning requirements.

It would also appear that the type of tax knowledge (noted as legal and procedural knowledge by Kamleitner et al. 2012:337)) is an important factor in small business owners' tax compliance, and lack of such knowledge may be an obstacle for even those willing to comply (Langham, Paulsen \& Hartel 2012:388).

Many small business owners deal with such tax knowledge deficiencies by employing the help of tax practitioners.

\section{Decision frames}

Small business owners pay taxes out of their own pocket, in contrast to employed taxpayers whose income tax is normally withheld at source. This represents a 'loss frame'. Kamleitner et al. (2012:338) refer to prospect theory to exhibit that 'the perceived pain of a loss is greater than the perceived pain caused by an equally sized non-gain'. They suggest that tax non-compliance could be a consequence of this loss frame (because of the painful experience of having to pay tax).
Kamleitner et al. (2012:338) also refer to 'mental accounting' to explain why small business owners may apply the loss frame. In this context, mental accounting means to keep book of different streams of income in different mental accounts, thereby being mindful that taxes due are not part of your income. If taxes are not perceived as different from other streams of income, paying taxes is experienced as a loss.

A further decision frame noted by Kamleitner et al. (2012:339) is based on reactance theory and suggests that 'paying taxes can be perceived as a reduction of one's own financial resources and as a limitation of one's financial freedom'. This is in accordance with the experience of tax payments as out of pocket losses.

\section{Specific tax situation}

Three factors are pointed out as considered relevant to the present study, namely industry type, business size and group norms.

Industry: Tax authorities have singled out certain industries that pose a greater risk of being non-compliant. Research performed by the CATA across 17 countries indicates that firms in the building and construction industries, selfemployed and contractors, taxi and transport drivers and real estate firms are most likely to engage in tax evasion and avoidance behaviours (The Commonwealth Association of Tax Administrators 2006:8). These are also industries that are more likely to operate in a cash-based environment. Coolidge and Ilic (2009:27) further propose that businesses belonging to industries where registration with a business association is expected are more likely to register for tax.

Business size: Yusof, Ling and Wah (2014:217-220) present evidence from several studies, suggesting that larger firms are more compliant than smaller firms. Their own study with 375 tax-audit cases in Malaysia confirms this and they propose that better internal control, proper accounting systems and better corporate governance play a role in larger firms being more tax compliant.

Group norms on tax compliance (social norm): Kornhauser's (2007) literature review on normative and cognitive aspects of tax compliance confirms that social norms are a factor influencing tax compliance.

Social norms can be described as the shared beliefs concerning the manner in which people should behave (Kornhauser 2007). This suggests that the tax compliance decision is also made with reference to the norms and observed behaviour of the general society in which taxpayers find themselves (Hashimzade et al. 2014:141; Wallschutzky 1985:380).

\section{Strategies to improve tax compliance}

A report from the Forum on Tax Administration: SME Compliance Sub-group emphasises the need to create an environment for small business which supports compliant 
behaviour and reduces opportunities for non-compliant behaviour (OECD 2012:9). The report presents a synthesis of current knowledge and experiences of compliance strategies as sourced from 12 participating OECD countries and recommends a 'right from the start' approach. In this approach, four dimensions are considered central to the compliance environment: (1) acting up-front, so that problems are prevented or addressed when they occur; (2) focus on the business processes dealing with the tax-related transactions; (3) making it easy to comply (and difficult not to) and (4) actively involving and engaging taxpayers, their representatives and other stakeholders, in order to achieve a better understanding of the taxpayer's perspective and to cooperate with third parties (OECD 2012:10).

From a South African perspective, SARS recognises that to ensure compliance, it must 'design, implement and manage a system that enhances perceptions of fairness, reduces administrative burden, and acts against infringements accurately and speedily' (SARS 2016a:34). South African Revenue Service declares that an understanding of the behaviour and reasons (root causes) that affect compliance is needed to instil a behavioural norm in which taxpayers and traders perceive compliance with legislation as a 'positive social value' and that interventions tailored to the needs of taxpayers are necessary (SARS 2016a:34). Strategies to achieve this are speedy services, quick turnaround times, quick payment of refunds, ease of trade, increased efforts to raise awareness by taxpayers of their legal obligations and making it reasonably easy to comply (SARS 2016a:34).

\section{Aim and purpose of the study}

The aim of the present article is to create a tax compliance risk profile and identify the factors that contribute the most to possible non-compliance by a population of guest house owners. By applying the available information of guest house owners in Soweto to Kamleitner et al.'s framework of factors influencing small business owners' tax compliance, the risk of tax non-compliance may be identified for this population.

From the results, practical and theoretical implications for policy makers and advisors may be derived and strategies for improving the tax compliance of this population may be suggested. This application of the framework will also verify the practicality of the framework as a conceptual tool for understanding and assessing the compliance risk of a population of small business owners.

\section{Method and design Study design}

The study employed a mixed methods approach in order to reach conclusions on the tax compliance risk profile of the population. A single method of data collection occurred in the form of structured questionnaires and the mixing occurred with the analysis of the data, namely descriptive statistics and a thematic analysis. Saunders, Lewis and
Thornhill (2012:166) postulate that the stage of the research process in which the mixing occurs is one way of identifying the characteristics of the mixed method research. In the present study, the mixing occurs at the analysis stage and is therefore characteristic of 'partially integrated mixed method research'.

Mixed methods research is frequently associated with pragmatism as a research framework (Creswell \& Plano Clark 2011). McKerchar (2010:79) explains that pragmatists 'freely choose the methods, techniques and procedures that best meet the needs and purpose of the research'. The authors of the present research are of the opinion that by using a mix of quantitative and qualitative analysis of the available data, the factors that influence tax compliance behaviour in small business owners can best be described for the population being explored.

\section{Setting and study population}

The township of Soweto has a long and illustrious history and heritage and is also a major South African tourist destination. According to the city of Johannesburg, Soweto's tourism industry contributes more than R143m to Gauteng's gross domestic product and more than 1 million tourists visited the township in 2013 (SME South Africa 2015). The estimated population statistics from the 2011 census approximate that there are 1.3 million people living in Soweto (Statistics South Africa 2011). The township's incredible consumer spending power cannot be ignored and recent estimates put it about R5 billion (SME South Africa 2015).

The tourism industry as a whole has been targeted as one of the key sectoral drivers for economic development and transformation in SA (Rogerson 2004). According to Rogerson (2004), government recognises that the unequal ownership structure in tourism needs to be addressed and a programme of transformation and support for the development of especially small tourism enterprises should be implemented. Additionally, the National Development Plan (South Africa 2012) emphasises the prominence of small and expanding firms in generating the majority of new jobs and in contributing to changing apartheid legacy patterns of business ownership. Given this renewed focus on SMMEs, it is submitted that an understanding of the tax situation of these entrepreneurs is a step towards gaining an understanding of the support they need in respect of complying with their tax obligations.

Ramutumbu (2016) reports that there is no existing database of small business owners of guest houses in Soweto. Therefore, she compiled a list of the business owners from a local telephone directory as well as using an online search for accommodation establishments in Soweto. The sample frame generated 32 guest houses in Soweto but the final number of completed questionnaires was 23. The fieldworkers did encounter setbacks with some of the businesses on the list. Three businesses had been converted into restaurants and were no longer operating as guest houses, another three 
could not be located at the stated business addresses and one had closed down. These were all classified as ineligible and were thus excluded from the list. In addition, two respondents opted not to participate in the survey.

\section{Data collection}

Data were collected by means of structured questionnaires that were administered face-to-face by a fieldworker and one of the researchers of the present study. It must be noted that the data were not collected solely for the purpose of the present article; however, both the quantitative and qualitative analyses were performed first-hand on selected data from the data set compiled by Ramutumbu's (2016) study. Onu (2016:15) observes that using questionnaires in tax compliance research is an acceptable data-collection tool that may provide useful indicators of the actions individuals take (such as tax compliance or non-compliance). Onu provides numerous examples of studies that have made use of questionnaires to survey people's attitudes towards the state and the fairness of the tax system to survey measures of tax morale and to survey taxpayers' attitudes towards others who evade taxes.

The data originated from Ramutumbu's (2016) survey of a sample of 23 black guest house owners or managers in the Soweto township. Ramutumbu gathered data on their attitude towards tax compliance and their tax morale, their perceptions towards fairness and trust in the South African tax system, their perceptions towards government and the treatment of taxpayers and their perceptions towards norms of compliance. This data were presented in the form of responses to a five-point Likert scale. Open-ended questions in which respondents were asked to reflect on the challenges and obstacles they experience in being tax compliant resulted in statements that could be analysed thematically.

\section{Data analysis}

Quantitative analysis: Descriptive statistics were used to report on the profile of the population based on the factors age and gender. This profile serves not only to describe the population but was also interpreted to assess the tax compliance risk normally associated with age and gender as evidenced by the literature from tax compliance behaviour studies. Responses to the questions on tax attitudes, perception of fairness and the social norm of tax compliance were analysed using frequency tables in order to determine the frequency in each category suggested by the Likert scale. These values were then interpreted to form an opinion on the extent to which the population displays an element of risk in possibly behaving tax non-compliant.

The qualitative analysis consisted of a thematic analysis of identifying and organising themes within the statements collected in response to the question 'what are the main challenges or obstacles that you experience when trying to behave in a tax compliant manner?' The data were coded by deductively assigning codes to statements made by the respondents as these relate to the factors 'perceived opportunity', 'knowledge requirements' and 'decision frames'. This can be described as a process of open coding which, according to Leedy and Ormrod (2010:143), is the process of scrutinising the data 'for commonalities that reflect categories or themes'.

\section{Relaibility and validity}

De Vos et al. (2011) are of the opinion that an instrument is considered valid when it actually measures the concept in question and that concept is measured accurately. According to Leedy and Ormrod (2015:100), validity is concerned with the soundness and effectiveness of the measuring instrument. A questionnaire was used by Ramutumbu (2016) as the measuring instrument to collect data. The questionnaire was designed and constructed based on existing questionnaires found in published empirical studies on tax compliance, many of which were mentioned in the literature review of the present article (see, e.g. Beers, LoPresti \& San Juan 2012; Oberholzer 2007). Mouton (2013) states that using existing instruments has certain advantages such as high validity and reliability that could have been demonstrated in a particular study. The questionnaire was also pilot-tested with postgraduate and undergraduate students with an expected level of education similar to that of the respondents to ensure that the language was understandable.

The thematic analysis was firstly performed separately by the researchers, whereafter a joint analysis was performed before reporting on final themes and categories. This increases the credibility of findings. In terms of transferability of the findings, it is acknowledged that the findings are not necessarily generalisable to other populations of SMMEs especially with regard to the findings based on person characteristics, knowledge requirements and industry specifications. However, the framework used and the process of analysis should be suitable for analysing small business tax compliance risks in any industry.

\section{Ethical considerations}

The original research project by Ramutumbu (2016) was granted ethical clearance by the Research Ethics Committee of the Faculty of Economic and Financial Sciences at the University of Johannesburg and includes the publication of further papers based on the data collected. All requirements for ethical research were met in the original study.

\section{Results and discussion}

The tables below present the results for the sample of guest house owners in Soweto for each of the factors referred to in the framework proposed by Kamleitner et al. (2012). The factors under consideration are (1) person (with the dimensions: age, gender, fairness perception and tax morale); (2) perceived opportunity; (3) knowledge requirements; (4) decision frames and (5) the specific tax situation (with dimensions: industry, business size and group norms on tax 
compliance). The results for each factor are displayed in a new table and are numbered Tables $1-5$. The results presented in Tables 1-5 are interpreted against existing theory and previous findings of other scholars on factors influencing tax compliance. The aim is to present an overall picture of the tax situation of this population of small business owners and to identify the areas that pose a risk to them from being compliant.

\section{Interpretation and discussion of Table 1}

\section{Age}

A recent meta-analysis of survey studies on the strength of the impact on compliance of demographic factors such as age, gender, education, and income from 111 countries published between 1958 and 2012 (Hofmann et al. 2017:65) serves as a credible source against which some of the findings in Table 1 can be interpreted. In respect of age and gender, the meta-analysis found a rather small but significant relation between the age of taxpayers and their tax compliance as well as between gender and tax compliance. "The older taxpayers are, the more they tend to comply with tax law', and 'females tend to comply with tax law more than men' (Hofmann et al. 2017:66). In addition, Kirchler (2007:157) reports that attitudes towards tax become more favourable as taxpayers age and Braithwaite et al. (2010) provide further empirical evidence that younger taxpayers are, in fact, less compliant than older taxpayers.

With the majority of the guest house owners in the present study being over 50 years of age, it would appear that this population may have a positive attitude towards tax (which was, in fact, confirmed by the positive results on their tax morale).

TABLE 1: Results of the analysis for the population surveyed using the factor 'Person'.

\begin{tabular}{|c|c|c|}
\hline Determinant & Perceptions & Result \\
\hline Age & - & $\begin{array}{l}\text { The majority of the population }(61 \%) \\
\text { is over } 55 \text { years of age. Only one } \\
\text { respondent is under the age of } 35\end{array}$ \\
\hline Gender & - & $\begin{array}{l}\text { Majority are female business } \\
\text { owners }(87 \%) \text {. }\end{array}$ \\
\hline \multirow[t]{3}{*}{$\begin{array}{l}\text { Fairness } \\
\text { perception }\end{array}$} & $\begin{array}{l}\text { Taxpayers have regarding the } \\
\text { fairness of tax laws. }\end{array}$ & $\begin{array}{l}\text { Results were very evenly spread, } \\
\text { with } 39 \% \text { disagreeing that tax laws } \\
\text { are unfair, } 21 \% \text { had no opinion and } \\
39 \% \text { agreed that tax laws are unfair. }\end{array}$ \\
\hline & $\begin{array}{l}\text { The manner in which the tax } \\
\text { authorities use their powers } \\
\text { to enact the laws. }\end{array}$ & $\begin{array}{l}\text { A total of } 43.5 \% \text { of the respondents } \\
\text { were of the opinion that the tax } \\
\text { authority is more concerned with } \\
\text { collecting as much as it can than } \\
\text { with collecting the correct amount } \\
\text { of tax. In another response, } 56.5 \% \\
\text { of the respondents felt that the tax } \\
\text { authority will not assist one if one } \\
\text { has difficulty paying your taxes. }\end{array}$ \\
\hline & Income distribution only. & $\begin{array}{l}\text { A total of } 47 \% \text { of the respondents } \\
\text { felt that the benefits they receive } \\
\text { as taxpayers are not reasonable } \\
\text { considering the amount of tax } \\
\text { they have to pay. }\end{array}$ \\
\hline Tax morale & $\begin{array}{l}\text { Own tax morale, as exhibited by: } \\
\text { - believing everyone should } \\
\text { correctly report all of their } \\
\text { income for tax purposes } \\
\text { - feeling a moral obligation to } \\
\text { report all income for tax } \\
\text { purposes correctly } \\
\text { - feeling embarrassed if not } \\
\text { reporting all income }\end{array}$ & $\begin{array}{l}\text { An overwhelming majority }(92 \%) \\
\text { agreed with the first two } \\
\text { statements (believing everyone } \\
\text { should correctly report income and } \\
\text { feeling a moral obligation to report } \\
\text { correctly). A total of } 74 \% \text { agreed } \\
\text { that they would feel embarrassed } \\
\text { if not reporting all income. }\end{array}$ \\
\hline
\end{tabular}

\section{Gender}

Attention is drawn again to the meta-analysis referred to above which found that women tend to be more tax compliant than men. Although Kastlunger et al. (2010:543) point out that there are inconsistencies in empirical studies on the level of compliance by male and female taxpayers, their experimental study conducted found that women are more compliant than men. However, a South African study found significant differences between the levels of income tax compliance for male and female business owners - with male participants being more likely to be tax compliant (Pretorius 2015). (It must be noted that Pretorius' study only tested for 'registration' compliance.)

Although it appears that gender does not play a major role as a factor of tax compliance and empirical studies render inconsistent results, it is noted in the present study that the majority of the guest house owners are women, which may imply a greater prospect of compliance.

\section{Fairness perception:}

'A high level of fairness perception should enhance trust in authorities and it should, finally, result in a higher level of tax compliance' (Casal et al. 2016:142). Murphy (2005:564) cites several empirical studies that indicate how being treated in a fair manner results in the higher trust in authorities by taxpayers, which consequently has the effect that taxpayers will be more inclined to comply with tax laws. Also, see studies supporting this finding by Levi, Tyler and Sacks (2008:24-25), Beers et al. (2012:70) and Hartl et al. (2015:14). Furthermore, a survey conducted amongst tax avoiders (Murphy 2004:206) found that taxpayers who experienced poor treatment from a tax authority as a result of their infractions (innocent or otherwise) displayed a decrease in trust in the authority which could ultimately result in resistance towards the tax authority.

In the present study, responses were mostly evenly spread on the issues of fairness of tax laws; the manner in which the tax authorities use their powers to enact the laws; and perceptions on fairness of income distribution. Perceptions by the respondents on fairness considerations were not overly favourable towards tax compliance. It would thus appear that fairness perception is an area of concern and may pose a risk for the tax compliance behaviour of this population of guest house owners.

This may be an even bigger concern in the current political climate in SA, given the fact that the President of SA, Cyril Ramaphosa, suspended the SARS commissioner in March 2018 as a result of a loss confidence in the commissioner's ability to lead SARS (The Presidency 2018). In addition, a Commission of Inquiry into tax administration and governance at the SARS (the Nugent Commission) was appointed by the President in May 2018 (The Presidency 2018). The commission has, to date, heard evidence of financial misconduct at the tax service from SARS employees, the office of the Tax Ombud and senior officials of 
National Treasury. This inquiry may not only negatively impact taxpayers' perception of SARS officials' ability to correctly administer tax assessment and collections, but may also raise the question if all taxes collected are correctly recorded and channelled to Treasury for fair distribution.

\section{Tax morale or norm of tax compliance}

Torgler, Schneider and Schaltegger (2010:3) mention that many researchers have studied the effect of tax morale on tax compliance (empirically and through experiments) and further propose that policy makers are increasingly interested in understanding the driving forces of tax morale as a factor influencing tax compliance. Torgler (2003:106-113) reports on empirical evidence, predicting that tax morale has a significant impact on tax compliance - higher tax morale strongly correlates with greater tax compliance.

Accordingly, Braithwaite et al. (2010) submit in their study that the lower levels of compliance are largely because of a significantly lower tax morale. Williams and Horodnic's (2015:94) empirical study further confirms that the lower the tax morale, the greater is the likelihood to participate in the shadow economy (both at the individual, population group and country level).

The results in Table 1 signify a high tax morale for the population under study and it is a favourable indication of tax-compliant behaviour. It means that the population has an intrinsic willingness to pay their taxes.

However, it may be that the tax morale of South Africans is under threat. Although South Africans have mostly been praised for their high tax morale in previous years (see SARS annual reports), concerns about a tax slippage have been expressed recently by Finance Minister Nhlanhla Nene (National Treasury 2018) as well as by SARS Head of Revenue and Research, Randall Carolissen, at the launch of the Tax Statistics 2017 publication (South African Government News Agency 2017). Meanwhile, SARS acting commissioner Mark Kingon said that 'compliance is of deep concern to SARS' (Business Day 2018). National Treasury (2018) and SARS (2016b) further claim that taxpayer morality has been eroded in recent years because of corruption and wasteful expenditure in the public sector. This leads to a dent in the social contract between taxpayers and the state because of a lack of timely government response to allegations of corruption and poor governance.

\section{Interpretation and discussion of Table 2}

\section{Perceived opportunities}

The CATA study on tax evasion and avoidance in member countries points out that the most attractive method of noncompliance by small businesses is under reporting of income and overstatement of deductions (The Commonwealth Association of Tax Administrators 2006:8). This is achieved by accounting misdeeds and failure to keep adequate records. Given the fact that the population under study expressed a lack of knowledge in understanding which expenses are deductible for tax purposes, it must be argued that this type of non-compliance may be because of error rather than intent. Their lack of knowledge may, in fact, deter the recognition of opportunities to evade tax. Further to this, many transactions in a guest house context may take place on a cash basis (for example, guests paying in cash for the accommodation and/ or meals). This opens up the opportunity for the under reporting of income.

Even though the results from the analysis did not provide conclusive evidence, it is submitted that, based on the high probability of error and prospects for cash transactions, opportunities for non-compliance (especially through accounting misdeeds) should be regarded as a high-risk factor for this population.

\section{Interpretation and discussion of Table 3}

\section{Knowledge requirements}

Tax knowledge is an important element of the self-assessment system of taxation and has been shown to have a positive effect on compliance behaviour (Fjeldstad \& Heggstad 2012; Hofmann, Hoelzl \& Kirchler 2008; Kamleitner et al. 2012; Niemirowski, Baldwin \& Wearing 2002; Palil 2010; Mansor, Saad \& Ibrahim 2004). Langham et al. (2012:364) found that when legal complexities and jargon create difficulty, 'awareness of the rules' is a better predictor of compliance than intention. Langham et al. (2012:387) further argue that 'complexity and obstacles to performance prevent even the

TABLE 2: Results of the analysis for the population surveyed using the factor 'Perceived opportunity'.

\begin{tabular}{ll}
\hline Determinant & Result \\
\hline $\begin{array}{l}\text { Possibilities } \\
\text { to deduct } \\
\text { non-deductible } \\
\text { expenses }\end{array}$ & $\begin{array}{l}\text { Possibilities to deduct non-deductible expenses are frequent as } \\
\text { private and domestic expenses could easily be entwined with } \\
\text { business expenditure. }\end{array}$ \\
$\begin{array}{l}\text { Anecdotal evidence suggests that some respondents find it } \\
\text { difficult to understand which expenses are deductible. }\end{array}$ \\
$\begin{array}{l}\text { Recognition of } \\
\text { opportunities }\end{array}$ & $\begin{array}{l}\text { More than } 60 \% \text { of the respondents recognise that tax laws } \\
\text { may have loopholes to reduce their taxes, but they are of the } \\
\text { opinion that only large business have these opportunities. }\end{array}$ \\
\hline
\end{tabular}

TABLE 3: Results of the analysis for the population surveyed using the factor 'Knowledge requirements'.

\begin{tabular}{|c|c|}
\hline Determinant & Result \\
\hline $\begin{array}{l}\text { Complexity of } \\
\text { reporting and } \\
\text { returning } \\
\text { requirements }\end{array}$ & $\begin{array}{l}\text { Quantitative results suggest that the majority of respondents } \\
(65 \%) \text { believe that tax rules are so complicated that it is very } \\
\text { difficult to get a tax return exactly right. Also, } 74 \% \text { believe that it is } \\
\text { difficult to keep up to date with changes in tax laws. }\end{array}$ \\
\hline $\begin{array}{l}\text { Employing help } \\
\text { of tax } \\
\text { practitioners }\end{array}$ & $\begin{array}{l}\text { The data revealed that } 83 \% \text { of the respondents make use of a tax } \\
\text { practitioner or accountant to handle the tax and accounting } \\
\text { functions of the business. }\end{array}$ \\
\hline $\begin{array}{l}\text { Type of tax } \\
\text { knowledge }\end{array}$ & $\begin{array}{l}\text { Anecdotal evidence from the respondents supports respondents' } \\
\text { belief of their own lack of knowledge to complete tax forms } \\
\text { correctly or to prepare accounts (bookkeeping) correctly. It } \\
\text { further supports their perception that tax laws are difficult to } \\
\text { understand and apply. } \\
\text { Some quotes from respondents to support this theme: } \\
\text { - 'Tax returns are difficult to understand'. } \\
\text { - 'Training was not helpful as there was no format given on how } \\
\text { the returns should look like'. } \\
\text { - 'It is difficult to keep all the receipts for the whole year, slips } \\
\text { get lost'. } \\
\text { - 'More knowledge so that we can do the books on our own'. } \\
\text { - 'it is difficult to write down all of your expenditure'. } \\
\text { Although the majority of respondents understand why they have } \\
\text { to pay tax (general tax knowledge), a large amount of anecdotal } \\
\text { evidence suggests that they have a lack of technical and procedural } \\
\text { tax knowledge. }\end{array}$ \\
\hline
\end{tabular}


most willing from complying' and Beers et al. (2012:66) opine that taxpayers 'may use complexity as a reason to justify noncompliance'.

It is evident from the results displayed in Table 3 that the respondents doubt their ability to understand and apply tax legislation correctly. It is also evident that they are more concerned with the procedural aspects (filling in the tax forms, record keeping, getting assistance from the tax office) than understanding the legislation. Most of the respondents employ tax practitioners for this purpose, but they do express a need to understand the procedures themselves. This is a positive result indicating their 'awareness of the rules'.

However, it is submitted that the factor 'tax knowledge requirements' appears to pose a risk of non-compliance for this population because inadequate knowledge may lead to unintentional errors.

\section{Interpretation and discussion of Table 4}

\section{Decision frames}

It can be presumed that this population regards paying taxes from a 'loss frame' because taxes are paid out of pocket. Although prospect theory suggests that people are more risk seeking in the loss domain than in the gain domain (Kamleitner et al. 2012:338), there is no evidence that any of the respondents actively seek (illegal) ways to reduce their tax burden. On the contrary, Ramutumbu (2016) concludes in her survey of the guest house owners that this population reveals a 'willingness to be tax compliant'.

The results in Table 4 further imply that in terms of 'mental accounting', it appears that the repondents are mindful of the payment of their taxes and some may keep a separate mental account. However, from further analysis of their responses, it can be concluded that a large number of them experience difficulties in keeping record of and reporting on their tax obligation. It is noted in the results displayed in Table 4 that respondents perceive taxes as depriving their businesses of much needed funds. This may suggest a decision frame of 'limitation of freedom'. Kamleitner et al. (2012:339) refer to studies conducted by Kirchler which perceived mixed results in the link between perceived limitation of freedom and hypothetical tax evasion.

TABLE 4: Results of the analysis for the population surveyed using the factor 'Decision frames'.

\begin{tabular}{ll}
\hline Determinant & Result \\
\hline $\begin{array}{l}\text { Prospect theory: } \\
\text { 'Loss' frame versus } \\
\text { a 'non-gain' frame }\end{array}$ & $\begin{array}{l}\text { Being small business owners, taxes are paid out of pocket } \\
\text { (not withheld at source). }\end{array}$ \\
$\begin{array}{ll}\text { Mental accounting } & \begin{array}{l}\text { An analysis of responses on challenges or obstacles in being } \\
\text { tax compliant reveals that the majority needs support in the } \\
\text { procedural aspects of taxation rather than a complete } \\
\text { understanding of the tax laws. This points to respondents being } \\
\text { mindful of taxes, in other words, keeping a separate mental } \\
\text { account of taxes to be collected and paid. }\end{array} \\
\begin{array}{ll}\text { Reactance theory: } \\
\text { limitation of }\end{array} & \begin{array}{l}\text { Some anecdotal evidence suggests that respondents believe } \\
\text { that paying taxes is depriving them of much needed funds to run }\end{array} \\
\text { their business profitably in order to grow and create more jobs. }\end{array}$ \\
\hline
\end{tabular}

Note: No direct questions on 'decision frames' were posed to respondents.
The population under study may be a high-risk group in terms of the way the tax decision is framed. Yet, it is submitted that there is little evidence that the 'loss frame' or 'perception of limitation of freedom' influences these taxpayers' compliance decision. It is suggested that future research could investigate typical decision frames of small business owners from various industries and examine the link with their tax compliance behaviour.

An interesting perspective on 'decision frame' may be derived from the findings of Coolidge and Ilic's (2009:28) analysis on perceived advantages and disadvantages of registering for tax. Their results indicate that reasons of perceived advantages such as 'better access to government services', 'being legal', 'access to and price of financing' and 'better opportunities for business growth' are strongly associated with the likelihood of registering with tax. It is proposed that a decision frame of 'perceived advantages' may positively be associated with tax compliance, but one should also be mindful that the cost of compliance does not outweigh such benefits.

\section{Discussion and interpretation of Table 5}

\section{Industry}

The OECD recognises that some industries may have norms and practices for taxpayers that favour non-compliance (OECD 2012:12). Yusof et al. (2014:230) confirm that 'types of industry' are one of the main factors influencing compliance behaviour of small- and medium-sized corporations in Malaysia. In line with an earlier statement made in the literature review section of the present study, their study found that the service and construction industries are more non-compliant as compared to other industries. They also cite an earlier study by Chan and Mo who found the serviceoriented industry to be less compliant. If one classifies guest houses as belonging to the 'service industry', it would appear that this type of business falls in a high-risk category for noncompliance. Moreover, guest houses could be inclined to operate on a cash basis with the possibility of limited supporting documents to be generated.

On the other hand, Coolidge and Ilic (2009:27) suggest that registration with a business association increases the likelihood of tax registration. If these guest houses could

TABLE 5: Results of the analysis for the population surveyed using the factor 'Specific tax situation'.

\begin{tabular}{|c|c|}
\hline Determinant & Result \\
\hline Industry & $\begin{array}{l}\text { The guest house industry could provide opportunities for cash- } \\
\text { based operations (receiving cash from guests, paying cash to } \\
\text { suppliers). Guest house owners are also mostly self-employed. }\end{array}$ \\
\hline Business size & $\begin{array}{l}\text { Almost } 80 \% \text { of the businesses surveyed employ fewer than five } \\
\text { employees. Most businesses are therefore regarded as small. }\end{array}$ \\
\hline $\begin{array}{l}\text { Group norms on } \\
\text { tax compliance } \\
\text { (social norm) }\end{array}$ & $\begin{array}{l}\text { - Data from three questions on the social norm of tax } \\
\text { compliance are available: } \\
\text { - Many small businesses do not report all their income. } \\
\text { - Most of my competitors do not report all their income. } \\
\text { all their income. } \\
\text { - Results were not conclusive. Although slightly more } \\
\text { respondents agreed than disagreed with the statements, } \\
\text { many respondents opted to select 'no opinion' to these } \\
\text { questions. } \\
\text { - A total of } 47 \% \text { of respondents were of the opinion that most } \\
\text { small businesses will not survive if they report all their income. }\end{array}$ \\
\hline
\end{tabular}


register with the South African Tourism Council for the benefit of being graded and to enhance their visibility especially to foreign tourists, it may improve their prospects of being tax compliant. It can thus be concluded that although this specific population falls within the high-risk industry especially because of the strong probability of operating on a cash basis, their association with the Tourism Council may mitigate this risk.

\section{Business size}

According to Yusof et al. (2014:231), larger firms are more compliant than smaller firms. Informal firms with more employees also appear more likely to register for tax (Coolidge \& Ilic 2009:8). The OECD observes that the limited size of an SMME may constrain administrative capacity and specialised competencies (for example, regarding tax issues) (OECD 2012:10).

The majority of the businesses in the survey can be regarded as small (employing fewer than five people). This factor therefore increases the risk for non-compliance of these guest house owners.

\section{Group norms on tax compliance (social norm)}

The shared beliefs about how members of a group should behave (social norms) may regulate the behaviour of the individual especially if the individual identifies strongly with the group (Wenzel 2005:504). Coolidge and Ilic (2009:28) propose that businesses not likely to register (or are neutral towards tax registration) perceive that a significantly high share of businesses 'similar to' themselves is not paying taxes 'at all'.

Fjeldstad, Schulz-Herzenberg and Sjursen (2012) also maintain that trust in other citizens to pay their share seems to be an important factor in tax-compliant behaviour. Other studies supporting a similar supposition are those of Beers et al. (2012:76), Cullis, Jones and Savoia (2012:165), Bobek, Roberts and Sweeney (2007:61) and Wenzel (2005:505).

Considering the results presented in Table 5 where it is posited that many respondents opted for 'no opinion' when asked about their perception of other small businesses' tax compliance, it can be advanced that this factor does not appear to exert a strong influence on their tax-compliant behaviour. It may be that the guest house owners do not identify strongly with other entrepreneurs in the same industry because there is no real connection between them in the form of belonging to an association or industry body. A report on entrepreneurship in SA suggests that cultural and social norms are significant factors that may impact on entrepreneurial intentions (Herrington, Kew \& Mwanga 2017), but (to the knowledge of the authors) no large-scale survey has been undertaken in SA to analyse the impact that cultural and social norms may have on tax compliance intentions.

Based on the literature referred to above and the inconclusive results as presented in Table 5, the authors of the present article are undecided about 'social norms' as an indicator of risk of non-compliance in the population under study.

\section{Creating a tax compliance risk profile}

The analysis of secondary data on a sample of guest house owners in Soweto, SA, is presented in Tables 1-5 and interpreted using supporting literature. The main finding in respect of each factor is presented below in order to give an overall impression of the tax compliance risk profile of this population.

\section{Factor: Person}

Age, gender and tax morale display favourable results in terms of positively influencing the guest house owners' tax compliance behaviour. However, tax morale is described as posing a big risk in the current environment in SA because of perceptions of corruption and wasteful expenditure in the public sector.

'Perceptions of fairness' appear to pose the biggest risk for non-compliant behaviour. The population's perceptions on the fairness of tax laws, the powers of tax authorities and the fairness of income distribution are not overly positive and may result in negatively influencing tax compliance behaviour. It is also discussed earlier how the current problems at SARS may be contributing to negative perceptions of the tax authority's competencies and fairness in dealing with taxpayers.

\section{Factor: Perceived opportunity}

It was argued that these small business owners may not actively be looking for opportunities to reduce tax payments, but opportunities do exist in the form of under reporting of income and over-deducting of expenses because of the possibility to transact with cash and the blurred lines between personal and business expenditure in a guest house context. This factor is therefore considered to contribute to the risk of non-compliance.

\section{Factor: Knowledge requirements}

Although it appears that the respondents have a high awareness of their tax obligation, their lack of knowledge (particularly in terms of procedural aspects, for example, completing tax forms) poses a high risk for being noncompliant.

\section{Factor: Decision frames}

The results provided little evidence that the 'loss frame' or 'perception of limitation of freedom' is present for this population and this factor is therefore undecided.

\section{Factor: Specific tax situation}

'Business size' could be considered a high-risk factor because most respondents' businesses are small and thus offer limited 
capacity for sufficient tax knowledge and skill. The 'accommodation industry' is also not regarded as favourable for tax compliance because of the prevalence of cash transactions and insufficient record keeping.

By synthesising the above conclusions, a profile of the tax compliance risk for the sample is created for a visual representation as depicted in Figure 2.

\section{Conclusion and recommendations}

This study demonstrated that the framework of factors influencing the tax compliance behaviour of small business owners proposed by Kamleitner et al. (2012) is a useful conceptual tool for analysing a specific population of small business owners. An interpretation of the results succeeds in highlighting the tax position of the small business owners and identifying areas of concern because of factors posing a risk for their compliant behaviour. It is suggested that similar research can be performed for other populations and industries in the small business sector.

It appears that this sample may be a high-risk group for noncompliance as the results indicate this for some of the factors and are summarised in Figure 2. The South African tax authority could address some of these identified risk areas with targeted strategies to encourage compliant behaviour. For example, tax authorities should take note of concerns by taxpayers on fair treatment and fair distribution of public goods and take action to ensure that it maintains legitimacy in the tax system. They should further be aware of what taxpayers perceive as obstacles to compliance, for example, knowledge deficits. South African Revenue Service, in keeping with its promise to 'make it as straightforward as possible for taxpayers and traders to register, file their returns, calculate their tax liability and pay the correct taxes and duties that are due' (SARS 2014:18), could consider introducing record-keeping and expense tracking mobile apps for small businesses. Online content in the form of brochures and guides and frequently asked questions to support and assist business owners with all aspects of tax are readily available on the SARS website, but no interactive tools are available to help small business owners with budgeting or calculating tax liabilities nor does it have a dedicated helpline for small businesses. D'Ascenzo (2015:93) describes how websites of leading tax agencies provide easy to follow step-by-step guidance for taxpayers, particularly

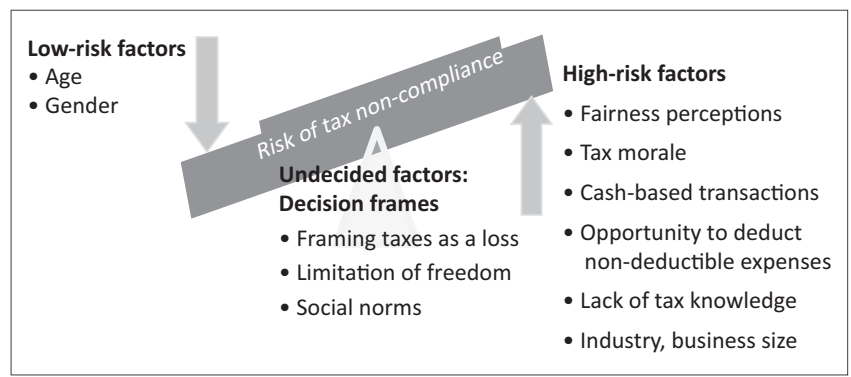

FIGURE 2: A profile of factors posing a risk for the compliance behaviour of guest house owners in Soweto. for individuals and small businesses. Tools such as 'decision trees, calculators and self-help tools to make compliance easier' are also common and a 'no strings attached' purely assistance visits to small businesses is another service offered by some tax agencies.

D'Ascenzo (2015:91) suggests that tax agencies should engage actively with industry associations, taxpayers and other government agencies to provide the agency with more insight into how to improve services and enhance compliance. It is, for example, possible that SARS could collaborate with business associations such as the Tourism Council in devising industry-specific education programmes on bookkeeping and tax procedures. This, in turn, could have a positive impact on decision frames and social norms being more favourable for tax compliant behaviour.

The SARS acknowledges that people must be empowered to meet their tax obligations (SARS 2016a:31-34). It is submitted that research on specific industries using a framework, such as proposed in the present study, could render invaluable information on risk factors, needs and frustrations of taxpayers to the revenue authority to enable this empowerment of taxpayers to comply voluntarily.

\section{Acknowledgements Competing interests}

The authors declare that they have no financial or personal relationships that may have inappropriately influenced them in writing this article.

\section{Author's contributions}

M.B. was responsible for conceptualisation of the article, literature review, analysis and interpretation of results. P.R. was responsible for data gathering, literature review, analysis and interpretation of data.

\section{References}

Ahmed, E. \& Braithwaite, V., 2005, 'Understanding small business taxpayers - issues of deterrence, tax morale, fairness and work practice', International Small Business Journal 23(5), 539-568.

Alm, J., Kirchler, E., Muehlbacher, S., Gangl, K., Hofmann, E., Kogler, C. et al., 2012, Rethinking the research paradigms for analyzing tax compliance behavior, Tulane Economics Working Paper Series: Working Paper 1210, Tulane University, New Orleans, LA.

Bazart, A. \& Bonein, A., 2014, 'Reciprocal relationships in tax compliance decisions', Journal of Economic Psychology 40, 83-102. https://doi.org/10.1016/j.joep 2012.10.002

Beers, T., LoPresti, E. \& San Juan, E., 2012, 'Factors influencing voluntary compliance by sole proprietors: Preliminary survey results', Taxpayer Advocate Service, IRS,
viewed 30 August 2018, from https://taxpayeradvocate.irs.gov/2012-Annualviewed 30 August 2018, from https://taxpayeradvocate.irs.gov/2012-Annualby-Small-Businesses-Preliminary-Survey-Results.pdf.

Bobek, D.D., Roberts, R.W. \& Sweeney, J.T., 2007, 'The social norms of tax compliance: Evidence from Australia, Singapore, and the United States', Journal of Business Ethics 74, 49-64. https://doi.org/10.1007/s10551-006-9219-x

Bornman, M., 2014, 'Principles for understanding, encouraging and rewarding voluntary tax compliance', PhD thesis, Department of Accountancy, University of Johannesburg.

Braithwaite, V., Reinhart, M. \& Smart, M., 2010, Tax non-compliance among the under30s: Knowledge, obligation or scepticism. Developing alternative frameworks for explaining tax compliance, Routledge, London.

Bureau for Economic Research, 2016, The small, medium and macro enterprise sector in South Africa, University of Stellenbosch, viewed 02 September 2018, from http://www.seda.org.za/Publications/Pages/Research-Publications.aspx. 
Business Day, 2018, April 4, Low tax compliance troubles SARS, viewed 12 September 2018, from https://www.businesslive.co.za/bd/national/2018-04-04-low-taxcompliance-troubles-sars/.

Carroll, J., 1987, 'Compliance with the law. A decision-making approach to taxpaying', Law and Human Behaviour 11(4), 319-335. https://doi.org/10.1007/BF01044744

Casal, S., Kogler, C., Mittone, L. \& Kirchler, E., 2016, 'Tax compliance depends on voice of taxpayers'. Journal of Economic Psychology 56, 141-150. https://doi.org/ 10.1016/j.joep.2016.06.005

Coolidge, J. \& Ilic, D., 2009, Tax compliance perceptions and formalization of small businesses in South Africa, Policy Research working paper no. WPS 4992, World Bank, Washington, DC, viewed 02 February 2018, from http://documents. worldbank.org/curated/en/419091468113058879/Tax-compliance-perceptionsand-formalization-of-small-businesses-in-south-Africa.

Creswell, J.W. \& Plano Clark, V.L., 2011, Designing and conducting mixed methods research, 2nd edn., Sage Publications, Inc., Thousand Oaks, CA.

Cullis, J., Jones, P. \& Savoia, A., 2012, 'Social norms and tax compliance: Framing the decision to pay tax', The Journal of Socio-Economics 41, 159-168. https://doi. org/10.1016/j.socec.2011.12.003

Cummings, R.G., Martinez-Vazques, J., McKee, M. \& Torgler, B., 2008, 'Tax morale affects tax compliance: Evidence from surveys and an artefactual field experiment',
Journal of Economic Behaviour and Organisation 70(3), 447-457. https://doi.org/ Journal of Economic Behaviour

D'Ascenzo., 2015, 'Global trends in tax administration', Journal of Tax Administration 1(1), 81-100. https://doi.org/10.2139/ssrn.3173515

De Vos, A., Strydom, H., Fouche, C. \& Delport, C., 2005, Research at grass roots, 3rd edn., Van Schaik, Pretoria.

DTC, 2013, The Davis tax Committee, viewed 05 September 2018, from http://www. taxcom.org.za/.

DTC, 2014, 'Small and medium enterprises: Taxation considerations interim report', The Davis Tax Committee, viewed 26 June 2016, from http://www.taxcom.org.za/ library.html.

Evans, C. \& Joseph, S., 2015, 'The South African tax system: Fit for purpose?', Journa of Tax Administration 1(2), 26-56.

Fjeldstad, O. \& Heggstad, K., 2012, Building taxpayer culture in Mozambique, Tanzania and Zambia: Achievements, challenges and policy recommendations, Chr Michelsen Institute and the International Center for Tax and Development, Michelsen Institute and the International Center for Tax and Development, Bergen, viewed 06 March 2019, from https:
building-taxpayer-culture-in-mozambique.

Fjeldstad, O.-H., Schulz-Herzenberg, C. \& Sjursen, I.H., 2012, 'Peoples' view of taxation in Africa: A review of research and determinants of tax compliance', CMI Working Paper 2012: 7, International Centre for Tax and Development.

Hartl, B., Hofmann, E., Gangl, K., Hartner-Tiefenthaler, M. \& Kirchler, E., 2015, ‘Does the sole Description of a tax authority affect tax evasion? - The impact of described coercive and legitimate power', PLoS One 10(4), 1-19. https://doi. org/10.1371/journal.pone.0123355

Hashimzade, N., Myles, G.D., Page, F. \& Rablen, M.D., 2014, 'Social networks and occupational choice: The endogenous formation of attitudes and beliefs about tax compliance', Journal of Economic Psychology 40, 134-146. https://doi. org/10.1016/j.joep.2012.09.002

Herrington, M., Kew, P. \& Mwanga, A., 2017, Global entrepreneurship monitor South Africa report 2016/17, Global Entrepreneurship Monitor, viewed 12 Septembe 2018, from https://www.gemconsortium.org/report/49833.

Hofmann, E., Hoelzl, E. \& Kirchler, E., 2008, 'Preconditions of voluntary tax compliance: Knowledge and evaluation of taxation, norms, fairness, and motivation to cooperate', Zeitschrift für Psychologie 216(4), 209-217. https://doi.org/10.1027/ 0044-3409.216.4.209

Hofmann, E., Voracek, M., Bock, C. \& Kirchler, E., 2017, 'Tax compliance across

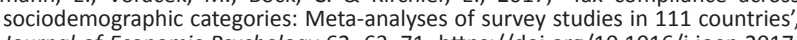
Journal of Economic Psychology 62, 63-71. https://doi.org/10.1016/j.joep.2017. 06.005

Junpath, S.V., Kharwa, S.E. \& Stainbank, L.J., 2016, 'Taxpayers' attitudes towards tax amnesties and compliance in South Africa: An exploratory study', South African Journal of Accounting Research 30(2), 97-119. https://doi.org/10.1080/1029195 4.2015.1070565

Kamleitner, B., Korunka, C. \& Kirchler, E., 2012, 'Tax compliance of small business owners: A review', International Journal of Entrepreneurial Behaviour and Research 18(3), 330-351. https://doi.org/10.1108/13552551211227710

Kastlunger, B., Dressler, S.G., Kirchler, E., Mittone, L. \& Voracek, M., 2010, 'Sex differences in tax compliance: Differentiating between demographic sex, genderdifferences in tax compliance: Differentiating between demographic sex, gender-
role orientation, and prenatal masculinization (2D:4D)', Journal of Economic role orientation, and prenatal masculinization (2D:4D), Journal of
Psychology 31(4), 542-552. https://doi.org/10.1016/j.joep.2010.03.015

Kirchler, E., 2007, The economic psychology of tax behaviour, Cambridge University Press, New York.

Kornhauser, M., 2007, 'Normative and cognitive aspects of tax compliance: Literature review and recommendations for the IRS regarding individual taxpayers', in II National Taxpayers Advocate, Annual Report to Congress, viewed 17 January 2018, from https://www.irs.gov/pub/tas/arc_2007_vol_2.pdf.

Langham, J., Paulsen, N. \& Hartel, C.E., 2012, 'Improving tax compliance strategies: Can the theory of planned behavior predict business compliance', eJournal of Tax Research 10(2), 364-402.

Leedy, P.D. \& Ormrod, J.E., 2010, Practical research: Planning and design, 9th edn., Pearson Education, Inc., Boston, MA.

Leedy, P.D. \& Ormrod, J.E., 2015, Practical research: Planning and design, 11th edn., Pearson Education, Inc., Boston, MA.
Levi, M., Tyler, T. \& Sacks, A., 2008, The reasons for compliance with law, Yale University, US Studies Centre, Sydney.

McKerchar, M., 2010, Design and conduct of research in tax, law and accounting, Thomson Reuters, Sydney.

McKerchar, M. \& Evans, C., 2009, 'Sustaining growth in developing economies through improved taxpayer compliance: Challenges for policy makers and revenue authorities', eJournal of Tax Research 7(2), 171-201. https://doi.org/10.2139/ ssrn.1415164

Mouton, J., 2013, How to succeed in your masters and doctoral studies, Van Schaik, Pretoria.

Murphy, K., 2004, 'The role of trust in nurturing compliance: A study of accused tax avoiders', Law and Human Behavior 28(2), 187-209. https://doi.org/10.1023/ B:LAHU.0000022322.94776.ca

Murphy, K., 2005, 'Regulating more effectively: The relationship between procedural justice, legitimacy, and tax non-compliance', Journal of Law and Society 32(4), 562-589. https://doi.org/10.1111/j.1467-6478.2005.00338.x

Naidoo, V., 2012, 'Tax morality and its effect on turnover tax', Master's dissertation, University of Johannesburg, Johannesburg.

National Treasury, 2018, Budget review 2018, viewed 10 September 2018, from www. treasury.gov.za.

National Treasury and South African Revenue Service, 2017, 2017 Tax statistics, viewed 10 September 2018, from http://www.treasury.gov.za/publications/ tax\%20statistics/default.aspx.

Niemirowski, P., Baldwin, S. \& Wearing, A., 2002, The determinants of Australian taxpayers' compliance behaviour: The influence of tax related values, beliefs, attitudes and behaviour, ATO Research Report, Commonwealth of Australia, Canberra.

Organisation for Economic Co-operation and Development (OECD), 2004, Compliance risk management: Managing and improving tax compliance- Guidance note Forum on Tax Administration: Compliance Sub-group. Centre for Tax Policy and Administration, viewed 06 March 2019, from https://www.oecd.org/tax/ administration/33818656.pdf.

Organisation for Economic Co-operation and Development (OECD), 2010, Understanding and influencing taxpayers' compliance behaviour, OECD, viewed 14 September 2018, from http://www.oecd.org/tax/administration/46274793.pdf.

Organisation for Economic Co-operation and Development (OECD), 2012, Right from the start: Influencing the compliance environment for small and medium enterprises, Forum on tax Administration: SME Compliance Sub-Group, OECD, Paris.

Olsen, N., 2015, 'Procedural justice for all: A taxpayer rights analysis of IRS earned income credit compliance strategy', Advances in Taxation 22, 1-35. https://doi. org $/ 10.1108 /$ S1058-749720150000022014

Onu, D., 2016, 'Measuring tax compliance attitudes: What surveys can tell us about tax compliance behaviour', Advances in Taxation 23, 179-190. https://doi. org/10.1108/S1058-749720160000023006

Palil, M.R., 2010, 'Tax knowledge and tax compliance determinants in self assessment system in Malaysia', Unpublished doctoral thesis, University of Birmingham, Birmingham.

Oberholzer, R., 2007, 'Perceptions of taxation: A comparative study of different population groups in South Africa', Doctoral thesis, University of Pretoria, Pretoria.

Oberholzer, R. \& Stack, E., 2009, 'Perceptions of taxation: A comparative study of different individual taxpayers in South Africa', Journal of Public Administration 44(3.1), 737-755.

Pickhardt, M. \& Prinz, A., 2014, 'Behavioral dynamics of tax evasion - A survey', Journal of Economic Psychology 40, 1-19. https://doi.org/10.1016/j.joep.2013. 08.006

Pretorius, M., 2015, 'South African small business' taxation registration compliance', Master's dissertation, University of Pretoria, Pretoria.

Ramutumbu, P., 2016, 'Tax compliance behaviour of guest house owners', Master's thesis, University of Johannesburg, Johannesburg.

Rogerson, C., 2004, 'Transforming the South African Tourism industry: The emerging black owned bed and breakfast economy', GeoJournal 60(3), 273-281. https:// doi.org/10.1023/B:GEJO.0000034734.81953.47

Mansor, M., Saad, N. \& Ibrahim, I., 2004, 'The self assessment system and its compliance costs', Journal of Financial Reporting and Accounting 2(1), 1-15, https://doi.org/10.1108/19852510480000657

South African Revenue Service (SARS), 2012, Compliance programme (2012-2016), SARS, viewed 12 March 2017, from https://www.sars.gov.za/AllDocs/SARSEntDoclib/ Ent/SARS-Strat-07-G02\%20-\%20Compliance $\% 2$ PProgramme $\% 202012 \% 20$ 2013\%20to\%202016\%202017\%20\%E2\%80\%93\%20External\%20Guide.pdf.

South African Revenue Service (SARS), 2014, Annual reports and strategic plans, SARS, viewed 05 September 2018, from http://www.sars.gov.za/About/Pages/AnnualReports-and-Strategic-Plans.aspx.

South African Revenue Service (SARS), 2016a, Strategic plan 2016/2017-2020/2021, SARS Annual Reports and Strategic Plans, viewed 12 September 2018, from http://www.sars.gov.za/About/Pages/Annual-Reports-and-Strategic-Plans.aspx.

South African Revenue Service (SARS), 2016b, Tax season 2016, South African Government, viewed 10 May 2017, from http://www.gov.za/speeches/tax season-2016-27-jun-2016-0000.

South African Revenue Service (SARS), 2018, SARS, Annual Performance Plan 2018/19, SARS Annual Reports and Strategic Plans, viewed 08 February 2019, from http:// www.sars.gov.za/About/Pages/Annual-Reports-and-Strategic-Plans.aspx. 
Saunders, M., Lewis, P. \& Thornhill, A., 2012, Research methods for business students, Pearson Education Limited, Essex.

SME South Africa, 2015, Sowetos-young-and-talented-entrepreneurs, SME South Africa, viewed 27 June 2016, from http://www.smesouthafrica.co.za/15417/Sowetosyoung-and-talented-entrepreneurs/.

Smulders, S., 2006, 'Taxation compliance burden for small business in South Africa', Master's dissertation, University of Pretoria, Pretoria.

South Africa, 2012, National development plan 2030, South Africa National Planning Commission, viewed 24 June 2016, from http://www.gov.za/sites/www.gov.za/ files/Executive $\% 20$ Summary-NDP $\% 202030 \% 20-\% 200$ ur $\% 2$ future $\% 20-\% 20$ make $\% 20$ it $\% 20$ work. pdf.

South African Government News Agency, 2017, SA increases use of tax stats to shape policies, viewed 06 March 2019, from https://www.sanews.gov.za/south-africa/ sa-increases-use-tax-stats-shape-policies.

Statistics South Africa, 2011, Statistics by place, Statistics South Africa, viewed 04 June 2014, from http://beta2.statssa.gov.za/?page_id=1021\&id=ekurhuleni-municipality.

Svetalekth, T., 2016, 'The complexity of tax simplification: Experiences from Thailand', in S. James, A. Sawyer \& T. Budak (eds.), The complexity of tax simplification. Experiences from around the world, pp. 187-208, Palgrave Macmillan, Hampshire.

The Commonwealth Association of Tax Administrators, 2006, Tax evasion and avoidance: Strategies and initiatives used by CATA member countries, Commonwealth Secretariat, Hampshire.

The Presidency, 2018, March 19, Statement on the suspension of SARS Commissioner, The Presidency. Republic of South Africa, viewed 18 September 2018, from http://www.thepresidency.gov.za/press-statements/statement-suspension-sarscommissioner.
Torgler, B., 2003, July, 'Tax morale: Theory and empirical analysis of tax compliance', Doctoral thesis, Universitat Basel, Basel.

Torgler, B., Schneider, F. \& Schaltegger, C., 2010, 'Local autonomy, tax morale, and the shadow economy', Public Choice 144, 293-321. https://doi.org/10.1007/s11127009-9520-1

Tyler, T., 2006, 'Restorative justice and procedural justice: Dealing with rule breaking', Journal of Social Issues 62(2), 307-326. https://doi.org/10.1111/j.1540-4560. 2006.00452.x

Van Dijk, M. \& Verboon, P., 2010, 'Trust in authorities as a boundary condition to procedural fairness effects on tax compliance', Journal of Economic Psychology 31(1), 80-91.

Wallschutzky, I., 1985, 'Possible causes of tax evasion', Journal of Economic Psychology 5, 371-384. https://doi.org/10.1016/0167-4870(84)90034-5

Wenzel, M., 2002, 'Tax compliance and the psychology of justice: Mapping the field', in V. Braithwaite (ed.), Taxing democracy, pp. 41-70, Ashgate, Aldershot.

Wenzel, M., 2005, Motivation or rationalisation: Causal relationships between ethics, norms and tax compliance, Working Paper no 63, Australia National University, Centre for Tax System Integrity, Canberra, viewed 12 August 2017, from https:// digitalcollections.anu.edu.au/bitstream/1885/43079/2/63.pdf.

Williams, C. \& Horodnic, I., 2015, 'Explaining and tackling the shadow economy in Estonia, Latvia and Lithuania: A tax morale approach', Baltic Journal of Economics 15(2), 81-98. https://doi.org/10.1080/1406099X.2015.1114714

Yusof, N.A., Ling, L.M. \& Wah, Y.B., 2014, 'Tax non-compliance among SMCs in Malaysia: Tax audit evidence', Journal of Applied Accounting Research 15(2), 215-234. https://doi.org/10.1108/JAAR-02-2013-0016 